\title{
The Effects of Different Types of Antioxidants (Se, Vitamin $E$ and Carotenoids) in Broiler Diets on the Growth Performance, Skin Pigmentation and Liver and Plasma Antioxidant Concentrations
}

-Author(s)

\section{Karadas $\mathrm{F}^{\mathrm{I}}$ \\ Erdoğan $S^{\prime}$ \\ Kor D' \\ Oto G" \\ Uluman $\mathrm{M}^{\prime \prime}$}

Yüzüncü Yıl University Agriculture Faculty, Department of Animal Science, Van, Turkey

" Yüzüncü Yıl University Research Hospital, Department of Pharmacy, Van, Turkey

III Kars Directorate of Provincial Food Agriculture and Livestock

\section{-Mail Address}

Corresponding author e-mail address Filiz Karadas

Department of Animal Science, Yuzuncu Yil University, 65080, Campus, Van/TURKEY

Phone: (0090) 5073067762

Email: fkaradas@yyu.edu.tr

\section{- Keywords}

Broiler, antioxidants, carotenoids, performance, immune response, pigmentation.

\section{ABSTRACT}

This study investigated the effects of the addition of different antioxidants to broiler diets on their live performance, liver antioxidant composition and concentrations, immune response, and meat and skin color. A total of 945 three-day-old Ross 308 broiler chicks of both genders were randomly allocated to one of nine dietary treatments $(n=105)$, with three replicates 35 chicks per pen, as follows: T1: control (commercially available corn-and soybean-based broiler diet); T2: selenium (control+0.5 mg/kg Sel-Plex ${ }^{\mathrm{TM} S e}$ yeast); T3: vitamin E (control+200 mg/ kg Kavimix-E-50 $\alpha$-tocopherol acetate); T4: lutein (control+100 mg/kg $5 \%$ Lutein Beads XB); T5: lycopene (control +100 mg/kg 5\% Lyco Beads XB);T6: canthaxanthin (control+25 mg/kg 10\% Carophyll ${ }^{\circledR}$ Red); T7: apoester (control+25 mg/kg 10\% Carophy|l ${ }^{\circledR} Y$ ellow); T8: lutein+zeaxanthin (control+25 mg/kg Xamacol ${ }^{\circledR}$ ); and T9: $\beta$-carotene (control+100 mg/kg $10 \%$ Rovimi $x^{\circledR}$ ). Feed (starter, grower, developer and finisher phases) and water were provided ad libitum for 42 days. Body weights, feed intake, feed conversion values and plasma carotene concentrations were recorded weekly, and liver antioxidant concentrations were recorded at the end of the experiment. Newcastle disease (LaSota) vaccination was performed on day 22. HI titers were measured on days 14, 21, 35 and 42 to determine the effects of the antioxidants on the immune system.

The addition of selenium, vitamin E, and carotenoid supplements to the commercial broiler diet significantly increased antioxidant accumulation in the liver and the plasma. All antioxidants assessed significantly improved the immune response. Selenium and vitamin E supplementation also significantly improved total carotenoid concentrations in the plasma. The carotenoids enhanced skin and meat color. None of the supplements tested influenced growth ( $p>0.05)$.

\section{INTRODUCTION}

Studies of birds in the wild have suggested that antioxidants are a limiting factor for laying females, as supplementation with antioxidants increases their transfer to eggs, which has beneficial consequences for specific offspring traits (Biard et al., 2005). Recent studies have shown that the injection of physiological amounts of antioxidants into eggs increases a major component of the acquired immune system without any adverse consequences on other offspring traits (Saino et al., 2003). Still, antioxidant concentrations are lower in maternal tissue than in yolk, suggesting that mothers actively transfer these compounds to eggs (Sunder \& Flachowsky, 2001; Surai, 2002; Rubolini et al., 2006). Therefore, during incubation, the incorporation of these compounds from egg yolk into the developing embryo and chick tissue (e.g., liver and blood) may substantially contribute to the antioxidant defenses of 
the offspring (Surai \& Sparks, 2001; Surai et al., 2001 a,b; Koutsos et al., 2003a; Karadas et al., 2005a).

Despite some results have suggested that carotenoids exhibit weak antioxidant effects (Costantini \& Møller, 2008), it is clear that these molecules also have immune-stimulating functions (Møller et al., 2000; Saino et al., 1997; 2003), which are important to combat the inhibitory effects of oxidative stress on immune responsiveness (Kurien \& Scofield, 2008; Costantini \& Møller, 2008; Galván et al., 2012). However, the beneficial functions of carotenoids vary depending on their source, and there is no consensus regarding the minimum and maximum dosages in broiler diets. In the wild birds, the egg yolk and tissue concentrations of $\mathrm{Se}$, carotenoids and vitamin $\mathrm{E}$ are many times higher than those in captive birds (Karadas et al., 2005b; Surai, 2002; 2006).

Carotenoids have also been demonstrated to affect broiler skin color, which is an important factor for consumer acceptance in many countries (Castañeda et al., 2005; Liu et al., 2008). Xanthophylls, which comprise a particular class of carotenoids, are the most prominent source of pigmentation in poultry feed (Goodwin, 1950); however, the typical cornand soybean-based commercial poultry diet does not supply the necessary amounts or types of xanthophylls required to produce a deep yellow skin (Castañeda et al., 2005).

Selenium (Se) is an essential trace mineral that is important for growth as a component of poultry nutrition (Surai, 2002; Selle at al., 2013). Se supplementation to animal feeds enhances the immune status of the animal and the ability of the immune system to respond to disease challenges (Tayeb \& Qader, 2012).

Vitamin E plays an important role in various biochemical and physiological processes, including antioxidant activity (Litta et al., 2014). Reportedly, the supplementation of 150 and $300 \mathrm{lU} / \mathrm{kg}$ vitamin $\mathrm{E}$ to feeds was shown to improve the immune response and to reduce the mortality of chickens challenged with E.coli (Tengerdy \& Nockels, 1975). Similar effects have been obtained with doses ranging from 100$300 \mathrm{mg} / \mathrm{kg}$ in turkeys and chickens challenged with colibacillosis, coccidiosis, and listeriosis (Colnago et al., 1984; Julseth, 1974).

In the past decade, considerable information has been published, indicating that vitamin $\mathrm{E}, \mathrm{Se}$, and carotenoids are major immune-stimulating agents (Surai, 2002). Despite the enormous amount of research focusing on vitamin $\mathrm{E}$ and $\mathrm{Se}$, few of these studies have compared the effects of vitamin E, Se and different sources and levels of carotenoids in broiler diets. Therefore, the present study aimed at evaluating the effects of dietary supplementation with high doses of Se and vitamin E, as well as with low and high doses of carotenoids, on broiler antioxidant systems, skin pigmentation and immune responses.

\section{MATERIALS AND METHODS}

\section{Animals and experimental design}

In total, 945 one-day-old commercial Ross 308 broiler chicks were purchased from a local supplier. All chicks were wing-banded for individual identification upon arrival at the university's poultry research farm. At 3 days of age, 105 chicks were randomly distributed among nine pens according to antioxidant and pigment treatments, with three replicates that had 35 chicks per pen, as follows:

Treatment 1: control diet (corn- and soybean-based commercial diet)

Treatment 2: control diet+0.5 mg/kg Seyeast (SelPlex ${ }^{\mathrm{TM}}$ 2000)

Treatment 3: control diet+200 $\mathrm{mg} / \mathrm{kg}$ vitamin E (Kavimix-E-50)

Treatment 4: control diet+100 mg/kg lutein (Lutein Beads XB 5\%)

Treatment 5: control diet+100 mg/kg lycopene (Lyco Beads XB 5\%)

Treatment 6: control diet+25 mg canthaxanthin (Carophyll ${ }^{\circledR}$ Red 10\%)

Treatment 7: control diet+25 mg/kg apo-ester (Carophyll ${ }^{\circledR}$ Yellow 10\%)

Treatment 8: control diet+25 mg/kg lutein (Xamacol $\AA 20)$

Treatment 9: control diet+100 mg/kg $\beta$-carotene (Rovimix ${ }^{\circledR} 10 \%$ ).

The commercial diet was purchased from a commercial supplier (Seher Tavukçuluk, Malatya). The supplements were provided by the manufacturers (Sel-Plex ${ }^{\mathrm{TM}} 2000$ from Alltech-Kentucky; Kavimix-E-50 from Kartal Kimya-Istanbul; 10\% Carophyll ${ }^{\circledR}$ Red, $10 \%$ Carophy $^{\circledR}{ }^{\circledR}$ Yellow and 10\% Rovimix ${ }^{\circledR}$ from DSM Nutrition-Istanbul; Xamacol $₫ 20$ from Novus-Brussels; and $5 \%$ Lutein Beads XB and 5\% Lyco Beads XB from Lyco Red Corp., New Jersey, USA) respectively. Detailed information regarding the nutritional content of the basal commercial diet is provided in Table 1.The supplements were added to the commercial feed using an electric mixer with a capacity of $40 \mathrm{~kg}$. The 
birds were provided with feed and water ad libitum throughout the experimental period. The commercial feed varied according to the following feeding schedule: starter feed, 0-11 days; grower feed, 12-21 days; developer feed, 22-35 days; and finisher feed, 36-42 days (Table 1 ).

Table 1 - Broiler Feed Composition ( $/ \mathrm{kg}$ )

\begin{tabular}{|c|c|c|c|c|}
\hline \multirow{3}{*}{$\begin{array}{l}\text { Feed ingredients } \\
(\mathrm{g} / \mathrm{kg})\end{array}$} & \multicolumn{4}{|c|}{ Phase } \\
\hline & Starter & Grower & Developer & Finisher \\
\hline & Days 1-11 & Days 12-21 & Days 23-35 & Days $36-42$ \\
\hline Corn & 415.82 & 430.84 & 460.18 & 485.75 \\
\hline Full-fat soybean & 300.00 & 250.00 & 250.00 & 250.00 \\
\hline Soybean & 114.00 & 120.00 & 84.23 & 75.00 \\
\hline Wheat & 75.00 & 75.00 & 75.00 & 58.00 \\
\hline Meat-chicken meal & 35.00 & 35.00 & 40.00 & 40.00 \\
\hline Meat-bone meal & 25.00 & 25.00 & 25.00 & 25.00 \\
\hline Dicalcium phosphate & 10.00 & 13.70 & 13.40 & 13.75 \\
\hline Limestone & 6.00 & 5.50 & 3.63 & 4.14 \\
\hline DL-Methionine & 3.00 & 3.53 & 3.44 & 3.14 \\
\hline Vegetable oil & 4.00 & 28.00 & 31.14 & 30.57 \\
\hline Salt & 2.77 & 2.04 & 1.82 & 1.61 \\
\hline L-Lysine & 2.71 & 3.65 & 4.13 & 4.69 \\
\hline Vitamin mixture $^{1}$ & 2.00 & 2.00 & 2.00 & 2.00 \\
\hline Mineral mixture ${ }^{2}$ & 2.00 & 2.00 & 2.00 & 2.00 \\
\hline Antifungal $^{3}$ & 2.00 & 2.00 & 2.00 & 2.00 \\
\hline Anticoccidial ${ }^{4}$ & 0.70 & 0.70 & 0.70 & 0.70 \\
\hline Sodium bicarbonate & - & 1.04 & 1.33 & 1.65 \\
\hline Total & 1000.00 & 1000.00 & 1000.00 & 1000.00 \\
\hline M. Energy & 3050 & 3150 & 3201 & 3226 \\
\hline Crude protein & 23.50 & 22.50 & 21.20 & 20.25 \\
\hline $\begin{array}{l}\text { Crude oil } \\
\text { Lysine }\end{array}$ & $\begin{array}{l}8.78 \\
1.46\end{array}$ & $\begin{array}{l}10.38 \\
1.44\end{array}$ & $\begin{array}{l}10.75 \\
1.40\end{array}$ & $\begin{array}{l}10.75 \\
1.38\end{array}$ \\
\hline Methionine & 0.66 & 0.66 & 0.64 & 0.60 \\
\hline Calcium & 1.00 & 0.98 & 0.98 & 1.00 \\
\hline $\begin{array}{l}\text { Phosphate } \\
\text { (available) }\end{array}$ & 0.49 & 0.49 & 0.48 & 0.48 \\
\hline
\end{tabular}

Vitamin premix ${ }^{1}$ added at $2 \mathrm{~g} / \mathrm{kg}$ yielded $12000 \mathrm{IU}$ vitamin $\mathrm{A}, 2400 \mathrm{IU}$ vitamin $\mathrm{D}_{3}, 32$ mg vitamin $\mathrm{E}^{*}, 4 \mathrm{mg} \mathrm{K}_{3^{\prime}}, 2.4 \mathrm{mg} \mathrm{B}_{1}, 4.8 \mathrm{mg} \mathrm{B}_{2^{\prime}} 4 \mathrm{mg} \mathrm{B}_{6^{\prime}} 0.016 \mathrm{mg} \mathrm{B}_{12^{\prime}}, 16 \mathrm{mg}$ niacin, $8 \mathrm{mg}$ calcium-D-pantothenate, $1.2 \mathrm{mg}$ folic acid, $0.06 \mathrm{mg}$ biotin, and $360 \mathrm{mg}$ choline chloride. Mineral premix ${ }^{2}$ added at $2 \mathrm{~g} / \mathrm{kg}$ yielded $80 \mathrm{mg}$ manganese, $60 \mathrm{mg}$ iron, $8 \mathrm{mg}$ copper, $0.5 \mathrm{mg}$ cobalt, and $2 \mathrm{mg}$ iodine. Antifungal ${ }^{3}$ Toxifix (toxin binder for poultry). ${ }^{4}$ Lasalocid sodium $15 \%$.

The birds live weight gain, feed intake, and feed conversion ratio were measured weekly from 1 to 6 weeks of age. A researcher with an animal care research ethics certificate (FK) collected blood and hepatic samples from two chickens from each replicate, for a total of six chickens per treatment. A blood sample was drawn from the jugular vein (Hoysak \& Weatherhead 1991) using a heparinized syringe and placed into an ice-cold tube. The plasma samples were stored at $-20^{\circ} \mathrm{C}$ for analyses of total carotenoids each week. At the end of the experiment, the chickens were sacrificed by cervical dislocation immediately after the blood sample was obtained.

\section{Liver analysis}

Liver carotenoid, vitamin A (retinol and retinol esters), vitamin $\mathrm{E}$ and coenzyme $\mathrm{Q}_{10}$ levels were measured using high-performance liquid chromatography (HPLC), as described previously by Surai et al., 2001 a. Tissue aliquots were vortexed in $0.7 \mathrm{~mL}$ of $5 \% \mathrm{NaCl}$. Ethanol $(1 \mathrm{~mL})$ was added, and the samples were homogenized for $1 \mathrm{~min}$. Hexane $(2 \mathrm{~mL})$ was added during homogenization. Following homogenization, the samples were centrifuged, and the carotenoidcontaining hexane phase was collected. The hexane extraction was repeated, and the combined hexane phase was dried using $\mathrm{N}_{2}$ gas. It was then re-dissolved in dichloromethane/methanol $(1: 1 \mathrm{v} / \mathrm{v})$.

The concentration of vitamin $\mathrm{E}(\alpha-, \gamma-$, and $\delta$-tocopherols, as well as $\alpha$ - and $\gamma$-tocotrienols) was determined as previously described (Surai et al., 2001a, b) using a Shimadzu Prominence HPLC system (Fluorescence Spectro fluorometer, Japan) fitted with a Hypersil Gold $5 \mu$ C 18 reverse-phase column $(10 \mathrm{~cm} \times 4.6$ $\mathrm{mm}$; Thermo, US) using a mobile phase of methanol/ water $(97: 3 \mathrm{v} / \mathrm{v})$ at a flow rate of $1.05 \mathrm{~mL} / \mathrm{min}$. The fluorescence detection of tocopherols and tocotrienols involved excitation and emission wavelengths of 295 and $330 \mathrm{~nm}$, respectively. Standard solutions of tocopherols and tocotrienols in methanol were used for instrument calibration. Coenzyme $\mathrm{Q}_{10}$ was analyzed in the same extract by injecting $50 \mu$ into the same HPLC system but using a Vidac 201TP54 column $(5 \mu \mathrm{m}, 25 \mathrm{~cm} \times 4.6 \mathrm{~mm})$, a mobile phase of ethanol/ methanol/2-propanol (70:15:15 by volume) and a flow rate of $1.5 \mathrm{~mL} / \mathrm{min}$ with diode array detection at 275 nm (Mattila \& Kumpulainen, 2001). A coenzyme $Q_{10}$ (Sigma) standard was used for calibration.

Total carotene levels were analyzed by injecting $10 \mu \mathrm{L}$ sample extraction into the same HPLC system, using a Waters NH2 column ( $5 \mu \mathrm{m}, 25 \mathrm{~cm} \times 4.6 \mathrm{~mm})$, a mobile phase of methanol/water ( $97: 3$ by volume) and a flow rate of $1.5 \mathrm{~mL} / \mathrm{min}$ with diode array detection at 444 nm (Surai \& Sparks, 2001).

The levels of retinol and retinol esters were determined by injecting $10 \mu \mathrm{L}$ sample extraction into the HPLC system using a Waters Supherisorb ODS 2, $5 \mu \mathrm{C}$ reverse-phase HPLC column $(25 \mathrm{~cm} \times 4.6$ $\mathrm{mm}$; Phase Separations Limited, UK), with diode array detection at $325 \mathrm{~nm}$ (Karadas et al., 2005a). 


\section{Immune response}

Half of the control chicks were selected as negative controls to verify effects of the control diet on the immune response to vaccination. Except for the negative controls, all birds were inoculated with a commercial B, strain LaSota (Lohmann Animal Health International (LAHI), Gainesville, GA) EID ${ }_{50}$ live vaccine tittered to a dose of at least $10^{6.5}$. The vaccines were administered with tap water that was dechlorinated by adding skimmed milk to $20 \mathrm{~L}$ of water. Blood samples were collected from the brachial veins of two birds per replicate (total of six birds) and centrifuged (3000 xg for 10 min) to obtain the serum for immune response analyses. The antibody response to vaccination was evaluated by NVD hemagglutination inhibition (HI) assays $\left(\log _{2} / 8 \mathrm{HA}\right)$, which were performed as described by Van Eck \& Goren (1991) at 13 days and 20 days post-vaccination, when the chickens were 35 and 42 days of age.

\section{Skin color evaluation}

Broiler carcasses were refrigerated at $4^{\circ} \mathrm{C}$ for $24 \mathrm{~h}$. Breast and leg colors were evaluated using a Chromameter (CR-400, Minolta, Japan) and expressed using the CIE-LAB dimensions of redness $\left(a^{*}\right)$, yellowness $\left(b^{*}\right)$ and lightness $\left(L^{*}\right)$; for each bird, three readings were performed, and the averages were calculated and recorded.

\section{Statistical analysis}

Statistical analysis was performed using SAS version 13.2 statistical software for Windows. Duncan's multiple range tests were used to assess differences between treatments, and a $\mathrm{p}<0.05$ was considered statistically significant (unless otherwise stated).

\section{RESULTS}

\section{Diet analyses}

Analysis of the feed ( $n=4$ samples) indicated that the concentrations of total carotenoids in the control diet were $7.40 \pm 0.69,9.54 \pm 0.76,13.95 \pm 0.12$, and $15.18 \pm 0.18 \mu \mathrm{g} / \mathrm{g}$ for the starter, grower, developer and finisher phases, respectively. Lutein, zeaxanthin, and $\beta$-carotene were the only carotenoids detected in the control diet, and they were found at the following concentrations ( $\%$ of total carotenoids): $43.51 \%$ lutein, $54.46 \%$ zeaxanthin, and $2.02 \% \beta$-carotene for the starter phase; $51.35 \%$ lutein, $46.22 \%$ zeaxanthin, and $2.43 \% \beta$-carotene for the grower phase; $49.82 \%$ lutein, $48.46 \%$ zeaxanthin, and $1.72 \% \beta$-carotene for the developer phase; and 53.72\%, lutein, $44.00 \%$ zeaxanthin, and $2.28 \% \beta$-carotene for the finisher phase.

The total carotenoid concentrations of the experimental groups are listed in Table 2. The carotenoid percentage changed as follows: $95.02 \%$ lutein for the 100-ppm-lutein-supplemented treatment(T4); 92.94\% lycopene for the lycopene-supplemented treatment (T5); $77.97 \%$ canthaxanthin for the canthaxanthinsupplemented treatment (T6); $74.02 \%$ apo-ester for the apo-ester-supplemented treatment (T7); 72.08\% lutein for the lutein-supplemented treatment (T8); and $88.45 \% \beta$-carotene for the $\beta$-carotene-supplemented treatment (T9).

\section{Bird performance}

Body weights, feed intake, feed conversion ratios, and mortality rates are presented in Table 3. In general, the body weights of the birds did not vary significantly among the treatment groups ( $p>0.05$ ).

Overall, feed intakes throughout the course of the experiment (weeks 0-6) were significantly lower in the $200 \mathrm{mg}$ vitamin $\mathrm{E}$ and $25 \mathrm{mg} / \mathrm{kg}$ apo-ester treatment groups compared with the $100 \mathrm{mg} / \mathrm{kg} \beta$-carotene treatment group $(p<0.05)$.

The feed conversion values did not vary significantly among the treatment groups ( $p>0.05$ ).

The mortality rate was significantly higher in the $\beta$-carotene treatment group compared with the

Table 2 - Total carotenoid concentrations of the experimental diets $(\mu \mathrm{g} / \mathrm{g})$

\begin{tabular}{|c|c|c|c|c|}
\hline \multirow[b]{2}{*}{ Treatments } & \multicolumn{4}{|c|}{ Total carotenoid concentration $(\mu \mathrm{g} / \mathrm{g})$ per phase of diet } \\
\hline & Starter & Grower & Developer & Finisher \\
\hline Control (Cont) & $7.40 \pm 0.69$ & $9.54 \pm 0.76$ & $13.95 \pm 0.27$ & $15.18 \pm 0.19$ \\
\hline Cont+0.5 Sel-Plex & $6.92 \pm 0.39$ & $8.42 \pm 0.69$ & $13.91 \pm 0.24$ & $16.56 \pm 0.27$ \\
\hline Cont+200 Vitamin E & $7.69 \pm 0.58$ & $9.20 \pm 0.48$ & $13.18 \pm 0.25$ & $16.67 \pm 0.16$ \\
\hline Cont+100 Lutein Beads & $107.11 \pm 1.52$ & $110.88 \pm 0.69$ & $114.46 \pm 5.36$ & $118.09 \pm 1.75$ \\
\hline Cont+100 Lyco Beads & $107.17 \pm 5.03$ & $108.87 \pm 3.62$ & $114.48 \pm 1.22$ & $115.23 \pm 0.64$ \\
\hline Cont+25 Canthaxanthin & $32.73 \pm 0.16$ & $33.77 \pm 1.30$ & $39.36 \pm 0.84$ & $42.93 \pm 1.26$ \\
\hline Cont+25 Apo-ester & $31.76 \pm 1.41$ & $32.85 \pm 0.30$ & $38.80 \pm 0.45$ & $42.21 \pm 0.83$ \\
\hline Cont+25 Xamacol & $29.47 \pm 0.47$ & $30.87 \pm 0.27$ & $38.77 \pm 1.13$ & $39.23 \pm 0.55$ \\
\hline Cont+100 $\beta$-carotene & $107.68 \pm 1.67$ & $108.98 \pm 1.30$ & $112.29 \pm 0.92$ & $114.85 \pm 0.79$ \\
\hline
\end{tabular}


Table 3 - Performance data by supplement treatment group

\begin{tabular}{|c|c|c|c|c|}
\hline \multirow[b]{2}{*}{ Treatments } & \multicolumn{4}{|c|}{ Performance data on day 42} \\
\hline & Body Weight (BW), g & Feed Intake (FI), g & $\mathrm{FCR}(\mathrm{Fl} / \mathrm{BW})$ & Mortality\% \\
\hline Control (Cont) & $2862 \pm 22.05$ & $4767 \pm 143.25^{\text {ba }}$ & $1.66 \pm 0.07$ & $5.71^{\text {ba }}$ \\
\hline Cont+0.5 Sel-Plex & $2890 \pm 52.92$ & $4409 \pm 197.93^{\text {ba }}$ & $1.53 \pm 0.10$ & $5.71^{\text {ba }}$ \\
\hline Cont+200 Vitamin E & $2823 \pm 63.59$ & $4224 \pm 48.01^{b}$ & $1.50 \pm 0.02$ & $2.86^{\mathrm{b}}$ \\
\hline Cont+100 Lutein Beads & $2833 \pm 91.34$ & $4517 \pm 34.38^{\text {ba }}$ & $1.59 \pm 0.07$ & $2.86^{\mathrm{b}}$ \\
\hline Cont+100 Lyco Beads & $2783 \pm 112.89$ & $4527 \pm 100.21^{\text {ba }}$ & $1.63 \pm 0.13$ & $7.62^{\text {ba }}$ \\
\hline Cont+25 Canthaxanthin & $2883 \pm 74.46$ & $4447 \pm 141.26^{\text {ba }}$ & $1.54 \pm 0.06$ & $2.86^{b}$ \\
\hline Cont+25 Apo-ester & $2670 \pm 55.00$ & $4245 \pm 232.26^{b}$ & $1.59 \pm 0.07$ & $7.62^{\text {ba }}$ \\
\hline Cont+25 Xamacol & $2760 \pm 86.22$ & $4473 \pm 235.96^{\text {ba }}$ & $1.62 \pm 0.09$ & $2.86^{\mathrm{b}}$ \\
\hline Cont+100 $\beta$-carotene & $2890 \pm 87.83$ & $4979 \pm 357.12^{\mathrm{a}}$ & $1.72 \pm 0.14$ & $9.52^{\mathrm{a}}$ \\
\hline $\mathrm{F}$ & 0.93 & 1.54 & 0.82 & 3.03 \\
\hline$p$ & 0.51 & 0.21 & 0.59 & 0.03 \\
\hline
\end{tabular}

a-c are used to indicate that within the same column, the values that do not share a common superscript are significantly different at the level of probability indicated.

vitamin $\mathrm{E}$, lutein beads, and canthaxanthin treatment groups $(p<0.05)$.

\section{Immune response}

The antibody titers for the different treatment groups are presented in Table 4 . Before vaccination on day 14 , significant differences were found between the other treatment groups and the $25 \mathrm{mg} / \mathrm{kg}$ Xamacol $^{\circledR}$ and $100 \mathrm{mg} / \mathrm{kg} \beta$-carotene groups $(p<0.05)$; these differences, however, disappeared on day 21 ( $p>0.05$ ). At 13 days post-vaccination, the antibody titers in all treatment groups improved significantly compared with those in the negative (unvaccinated) control group (Table 4). Significant improvements were also found in the positive (vaccinated) control group $(p<0.05)$. No significant differences were found in the stimulated immune responses of the positive (vaccinated) control group and the groups supplemented with $25 \mathrm{mg} / \mathrm{kg}$ Xamacol $^{\circledR}$ and $100 \mathrm{mg} / \mathrm{kg} \beta$-carotene. Interestingly, at 20 days post-vaccination (42 days of age), the $\mathrm{HI}$ response of the negative control group was significantly improved compared with those of all of the experimental treatment groups, although it did not improve compared with that of the positive control group $(\mathrm{p}<0.05)$.

\section{Plasma total carotenoid concentration}

The total plasma carotenoid concentrations by week are presented in Table 5. All of the antioxidant treatment groups had significantly higher total plasma carotenoid concentrations compared with those of the control group during week 1 of the experiment. However, in week 2, the total plasma carotenoid concentration of the vitamin $\mathrm{E}$ treatment group was significantly higher than those of all of the other experimental groups, and although the total plasma carotenoid concentration of the Se treatment group was lower than that of the vitamin $E$ treatment

Table 4 - Vaccine anticor hemagglutination titers $\left(\log _{2} / 8 \mathrm{HI}\right)\left(\operatorname{mean} \pm \mathrm{SE} ; \log _{2} ; \mathrm{n}=6\right)$

\begin{tabular}{|c|c|c|c|c|}
\hline \multirow{3}{*}{ Treatments } & \multicolumn{3}{|c|}{ Days } & \multirow{3}{*}{ D42 } \\
\hline & \multirow[b]{2}{*}{ D14 } & \multicolumn{2}{|l|}{ D21 } & \\
\hline & & & D35 & \\
\hline Negative contro|* & * & * & $6.17 \pm 0.31^{d}$ & $9.50 \pm 0.42^{\mathrm{a}}$ \\
\hline Positive control (Cont) & $6.33 \pm 0.21^{c}$ & $5.67 \pm 0.21$ & $7.83 \pm 0.17^{c}$ & $8.17 \pm 0.31^{\text {ba }}$ \\
\hline Cont+0.5 Sel-Plex & $5.83 \pm 0.17 c$ & $5.07 \pm 0.22$ & $9.83 \pm 0.40^{\text {ba }}$ & $8.00 \pm 0.36^{b}$ \\
\hline Cont+200 Vitamin E & $5.83 \pm 0.31^{c}$ & $5.66 \pm 0.18$ & $10.00 \pm 0.26^{\text {ba }}$ & $6.67 \pm 0.49^{b c}$ \\
\hline Cont+100 Lutein Beads & $6.00 \pm 0.00^{c}$ & $6.00 \pm 0.00$ & $10.17 \pm 0.40^{a}$ & $7.33 \pm 0.56^{b c}$ \\
\hline Cont+100 Lyco Beads & $6.00 \pm 0.26^{c}$ & $5.76 \pm 0.12$ & $9.33 \pm 0.49^{\text {ba }}$ & $6.17 \pm 0.31^{c}$ \\
\hline Cont+25 Canthaxanthin & $6.17 \pm 0.17 c$ & $6.00 \pm 0.02$ & $10.00 \pm 0.26^{\text {ba }}$ & $7.00 \pm 0.63^{b c}$ \\
\hline Cont+25 Apo-ester & $6.17 \pm 0.31^{c}$ & $5.67 \pm 0.21$ & $9.83 \pm 0.31^{\text {ba }}$ & $6.67 \pm 0.61^{b c}$ \\
\hline Cont+25 Xamacol & $7.00 \pm 0.26^{b}$ & $6.17 \pm 0.40$ & $9.50 \pm 0.43^{c}$ & $7.83 \pm 0.40^{b}$ \\
\hline Cont+100 $\beta$-carotene & $7.67 \pm 0.21^{\mathrm{a}}$ & $6.17 \pm 0.11$ & $8.83 \pm 0.14^{\mathrm{bc}}$ & $7.17 \pm 0.48^{b c}$ \\
\hline $\mathrm{P}$ & 0.00015 & 0.97 & 0.00018 & 0.00029 \\
\hline $\mathrm{F}$ & 7.23 & 0.47 & 11.97 & 4.16 \\
\hline
\end{tabular}

*Negative control, chicks from control groups but not vaccinated.

a-d are used to indicate that within the same column, the values that donot share a common superscript are significantly different at the level of probability indicated. 
Table 5 - Plasma total carotene concentrations $(\mu \mathrm{g} / \mathrm{g})$ by age

\begin{tabular}{|c|c|c|c|c|c|c|}
\hline \multirow{2}{*}{ Treatments } & \multicolumn{6}{|c|}{ Weeks of age, $n=6$} \\
\hline & 1 & 2 & 3 & 4 & 5 & 6 \\
\hline Control (Cont) & $5.55 \pm 0.36^{f}$ & $6.51 \pm 0.72^{\mathrm{cb}}$ & $2.49 \pm 0.70^{e}$ & $3.36 \pm 0.58^{d c}$ & $1.54 \pm 0.31^{\mathrm{e}}$ & $0.98 \pm 0.14^{e}$ \\
\hline Cont+0.5 Sel-Plex & $8.26 \pm 0.25^{e}$ & $8.54 \pm 0.60^{b}$ & $4.87 \pm 0.63^{d c}$ & $3.88 \pm 0.31^{\mathrm{dc}}$ & $1.88 \pm 0.14^{e}$ & $1.62 \pm 0.36^{e}$ \\
\hline Cont+200 vitamin $\mathrm{E}$ & $9.47 \pm 0.63^{\text {ed }}$ & $11.02 \pm 1.08^{\mathrm{a}}$ & $7.15 \pm 1.22^{\mathrm{bc}}$ & $4.92 \pm 0.44^{c}$ & $3.32 \pm 0.18^{\text {de }}$ & $1.51 \pm 0.36 \mathrm{e}$ \\
\hline Cont+100 Lutein Beads & $11.42 \pm 0.93^{c b}$ & $6.16 \pm 0.71^{c}$ & $8.69 \pm 0.48^{\text {ba }}$ & $6.91 \pm 0.74^{b}$ & $6.54 \pm 0.57^{\text {ba }}$ & $7.93 \pm 0.91^{b}$ \\
\hline Cont+100 Lyco Beads & $13.09 \pm 0.76^{b}$ & $3.15 \pm 0.49^{d}$ & $6.73 \pm 0.48^{\mathrm{bc}}$ & $3.91 \pm 0.57^{d c}$ & $3.72 \pm 0.49^{d c}$ & $4.22 \pm 0.45^{d}$ \\
\hline Cont+25 Canthaxanthin & $12.44 \pm 0.65^{b}$ & $4.93 \pm 0.27^{\mathrm{cd}}$ & $10.59 \pm 1.15^{a}$ & $9.53 \pm 1.27^{a}$ & $5.23 \pm 0.64^{b c}$ & $6.29 \pm 0.33^{c}$ \\
\hline Cont+25 Apo-ester & $10.22 \pm 0.44^{c d}$ & $6.44 \pm 0.83^{c}$ & $7.37 \pm 0.49^{b}$ & $2.57 \pm 0.41^{\text {de }}$ & $8.19 \pm 1.04^{\mathrm{a}}$ & $7.47 \pm 0.70^{c b}$ \\
\hline Cont+25 Xamacol & $16.57 \pm 0.56^{a}$ & $6.81 \pm 0.66^{\mathrm{cb}}$ & $7.01 \pm 0.61^{b c}$ & $3.53 \pm 0.41^{d c}$ & $7.93 \pm 0.55^{a}$ & $10.38 \pm 0.57^{a}$ \\
\hline Cont+100 $\beta$-carotene & $9.37 \pm 0.64^{\mathrm{ed}}$ & $5.97 \pm 0.37 c$ & $4.41 \pm 0.37^{\mathrm{de}}$ & $1.36 \pm 0.37^{e}$ & $3.23 \pm 0.83^{\mathrm{de}}$ & $2.48 \pm 0.29^{e}$ \\
\hline $\mathrm{F}$ & 26.72 & 10.56 & 10.54 & 15.44 & 17.95 & 44.52 \\
\hline$P_{\text {sig }}$ & 0.00014 & 0.00031 & 0.00014 & 0.00013 & 0.00019 & 0.00029 \\
\hline
\end{tabular}

a-f are used to indicate that within the same column, the values that do not share a common superscript are significantly different at the level of probability indicated.

group, it was significantly higher than those of all of the other pigment-supplemented treatment groups $(p<0.05)$. These differences between the vitamin $\mathrm{E}$ and Se treatment groups disappeared during weeks 4, 5 and 6 . During week 3, all of the experimental groups except for the $100 \mathrm{mg} / \mathrm{kg} \beta$-carotene-supplemented group had significantly higher total plasma carotenoid concentrations than the control group $(p<0.05)$. In week 4 after vaccination, the concentrations in the 25 $\mathrm{mg} / \mathrm{kg}$ canthaxanthin and the $100 \mathrm{mg} / \mathrm{kg}$ Lutein Bead groups were significantly improved compared with the concentrations in all of the other experimental treatment groups. These two groups had been flowed up with the vitamin E supplementation treatment. However, lower total carotenoid concentrations were recorded in the $\beta$-carotene-supplemented treatment group $(p<0.05)$.

\section{Liver antioxidant concentrations}

The liver antioxidant (total carotenoids, $\alpha$ - and $\gamma$-tocopherols, total vitamin $\mathrm{E}$ and coenzymeQ $_{10}$ ) concentrations are presented in Table 6. The total carotenoid concentrations in the liver varied among the treatment groups as follows: canthaxanthin>apoester $\geq$ Xamaco $^{\circledR}>$ Lutein Beads $\geq$ Lyco Beads $>\beta$ carotenoid $\geq$ vitamin $E \geq$ Sel-ple $\geq$ control $(p<0.05)$. The levels of $\alpha$ - and $\gamma$-tocopherols and coenzyme $Q_{10}$ were not affected by the treatments; however, the liver vitamin $\mathrm{E}$ concentrations (total vitamin $\mathrm{E}$ and $\alpha$-tocopherol) were significantly higher in Vitamin E supplemented than those in the other treatment groups (Table 6).

The liver retinol and retinol ester concentrations at 42 days of age are presented in Table 7. As the table shows, $\beta$-carotene supplementation significantly improved the total vitamin A concentrations in the liver $(p<0.05)$ compared with all of the other experimental treatments. The treatments did not affect the retinol concentrations ( $p>0.05$ ); however, $\beta$-carotenoid supplementation had a significant positive effect on the R-linoleate, R-oleate, R-palmitate and R-stearate concentrations $(p<0.05)$. In addition, compared with $\beta$-carotene supplementation

Table 6 - Antioxidant composition of the liver at 42 days of age $(\mu \mathrm{g} / \mathrm{g})$

\begin{tabular}{llllll}
\hline \multirow{2}{*}{ Treatments } & \multicolumn{5}{l}{ Antioxidants in the liver; $\mathrm{n}=6$} \\
\cline { 2 - 6 } & Total carotene & $\delta$-Tocopherol & $\alpha$-Tocopherol & Total vitamin $\mathrm{E}$ & Coenzyme $_{10}$ \\
\hline Control (Cont) & $2.67 \pm 0.60^{\mathrm{e}}$ & $0.88 \pm 0.19$ & $47.94 \pm 10.47^{\mathrm{b}}$ & $48.82 \pm 10.56^{\mathrm{b}}$ & $154 \pm 9.61$ \\
Cont+0.5 Sel-Plex & $3.28 \pm 0.63^{\mathrm{e}}$ & $0.91 \pm 0.18$ & $51.41 \pm 11.12^{\mathrm{b}}$ & $52.32 \pm 11.29^{\mathrm{b}}$ & $144 \pm 12.11$ \\
Cont+200 Vitamin $\mathrm{E}$ & $3.95 \pm 0.42^{\mathrm{e}}$ & $1.02 \pm 0.21$ & $90.32 \pm 5.48^{\mathrm{a}}$ & $91.35 \pm 5.36^{\mathrm{a}}$ & $133 \pm 15.58$ \\
Cont+100 Lutein Beads & $9.73 \pm 0.96^{\mathrm{cd}}$ & $1.45 \pm 0.37$ & $47.39 \pm 9.31^{\mathrm{b}}$ & $48.84 \pm 9.11^{\mathrm{b}}$ & $139 \pm 10.69$ \\
Cont+100 Lyco Beads & $9.02 \pm 1.82^{\mathrm{d}}$ & $1.28 \pm 0.18$ & $45.63 \pm 8.79^{\mathrm{b}}$ & $46.91 \pm 8.88^{\mathrm{b}}$ & $159 \pm 21.75$ \\
Cont+25 Canthaxanthin & $32.54 \pm 5.85^{\mathrm{a}}$ & $0.95 \pm 0.17$ & $47.20 \pm 14.96^{\mathrm{b}}$ & $48.14 \pm 15.12^{\mathrm{b}}$ & $141 \pm 27.91$ \\
Cont+25 Apo-ester & $23.11 \pm 3.80^{\mathrm{b}}$ & $0.93 \pm 0.09$ & $33.92 \pm 7.40^{\mathrm{b}}$ & $34.84 \pm 7.43^{\mathrm{b}}$ & $130 \pm 15.57$ \\
Cont+25 Xamacol & $16.40 \pm 2.34^{\mathrm{b}}$ & $0.87 \pm 0.10$ & $42.88 \pm 5.37^{\mathrm{b}}$ & $43.758 \pm 5.36^{\mathrm{b}}$ & $152 \pm 12.28$ \\
Cont+100 $\beta$-carotene & $6.11 \pm 0.52^{\mathrm{d}}$ & $1.56 \pm 0.40$ & $45.99 \pm 1.93^{\mathrm{b}}$ & $47.55 \pm 1.96^{\mathrm{b}}$ & $130 \pm 11.14$ \\
\hline $\mathrm{F}$ & 17.45 & 1.29 & 3.15 & 3.11 & 0.40 \\
$\mathrm{P}_{\text {sig }}$ & 0.0003 & 0.27 & 0.007 & 0.007 & 0.91 \\
\hline
\end{tabular}

$a-b$ are used to indicate that within the same column, the values that donot share a common superscript are significantly different at the level of probabilityindicated. 
Table7 - Liver retinol and retinol ester concentrations at 42 days of age $(\mu \mathrm{g} / \mathrm{g})$

\begin{tabular}{lllllll}
\hline \multirow{2}{*}{ Treatments } & \multicolumn{5}{c}{ Retinol and retinol esters in the liver; $\mathrm{n}=6$} \\
\cline { 2 - 7 } & Retinol & R-linoleate & R-oleate & R-palmitate & R-stearate & Total vit. A \\
\hline Control (Cont) & $5.81 \pm 0.91$ & $9.22 \pm 1.96^{\mathrm{b}}$ & $16.49 \pm 1.41^{\mathrm{b}}$ & $32.48 \pm 1.40^{\mathrm{a}}$ & $9.12 \pm 2.22^{\mathrm{c}}$ & $73.10 \pm 2.33^{\mathrm{b}}$ \\
Cont+0.5 Sel-Plex & $6.27 \pm 1.45$ & $7.99 \pm 0.43^{\mathrm{b}}$ & $8.52 \pm 0.52^{\mathrm{d}}$ & $14.34 \pm 1.14^{\mathrm{cb}}$ & $13.20 \pm 1.28^{\mathrm{cb}}$ & $50.31 \pm 2.72^{\mathrm{fed}}$ \\
Cont+200 Vitamin E & $6.47 \pm 1.40$ & $8.64 \pm 0.52^{\mathrm{b}}$ & $11.53 \pm 0.25^{\mathrm{c}}$ & $13.00 \pm 2.11^{\mathrm{b}}$ & $14.90 \pm 1.31^{\mathrm{cb}}$ & $54.89 \pm 3.13^{\mathrm{ced}}$ \\
Cont+100 Lutein Beads & $6.27 \pm 0.88$ & $7.49 \pm 0.53^{\mathrm{b}}$ & $11.59 \pm 0.79^{\mathrm{c}}$ & $19.36 \pm 1.99^{\mathrm{b}}$ & $16.26 \pm 0.40^{\mathrm{cb}}$ & $60.97 \pm 2.30^{\mathrm{cbd}}$ \\
Cont+100 Lyco Beads & $4.70 \pm 1.11$ & $4.85 \pm 0.90^{\mathrm{b}}$ & $7.39 \pm 0.66^{\mathrm{d}}$ & $13.12 \pm 1.01^{\mathrm{cb}}$ & $17.26 \pm 1.24^{\mathrm{cb}}$ & $47.32 \pm 2.86^{\mathrm{fed}}$ \\
Cont+25 Canthaxanthin & $7.17 \pm 2.09$ & $6.97 \pm 0.59^{\mathrm{b}}$ & $7.38 \pm 1.28^{\mathrm{d}}$ & $8.46 \pm 1.33^{\mathrm{c}}$ & $14.03 \pm 3.29^{\mathrm{cb}}$ & $39.26 \pm 3.44^{\mathrm{f}}$ \\
Cont+25 Apo-ester & $8.76 \pm 1.85$ & $8.75 \pm 1.10^{\mathrm{b}}$ & $7.70 \pm 1.05^{\mathrm{d}}$ & $18.90 \pm 2.44^{\mathrm{b}}$ & $21.59 \pm 1.31^{\mathrm{b}}$ & $65.71 \pm 4.74^{\mathrm{cb}}$ \\
Cont+25 Xamacol & $9.17 \pm 1.21$ & $7.51 \pm 0.64^{\mathrm{b}}$ & $6.11 \pm 0.52^{\mathrm{d}}$ & $7.21 \pm 0.92^{\mathrm{c}}$ & $11.12 \pm 1.23^{\mathrm{c}}$ & $41.11 \pm 2.04^{\mathrm{fe}}$ \\
Cont+100 $\beta$-carotene & $5.38 \pm 2.54$ & $16.3 \pm 2.95^{\mathrm{a}}$ & $20.61 \pm 1.22^{\mathrm{a}}$ & $31.06 \pm 4.97^{\mathrm{a}}$ & $36.58 \pm 7.93^{\mathrm{a}}$ & $109.57 \pm 10.16^{\mathrm{a}}$ \\
\hline $\mathrm{F}$ & 1.03 & 5.46 & 26.43 & 15.97 & 6.73 & 23.27 \\
$\mathrm{P}_{\text {sig }}$ & 0.43 & 0.00011 & 0.00023 & 0.00014 & 0.00019 & 0.00080 \\
\hline
\end{tabular}

a-f are used to indicate that within the same column, the values that donot share a common superscript are significantly different at the level of probability indicated.

and the control diet, pigment, vitamin E and selenium supplementation had negative effects on retinol ester accumulation $(p<0.05)$.

\section{Skin and meat pigmentation}

The skin and meat pigmentation findings are presented in Tables 8,9 and 10. Table 8 shows that significant improvements in breast and leg skin and meat redness $\left(a^{*}\right)$ were only found in the $25 \mathrm{mg} / \mathrm{kg}$ canthaxanthin treatment group $(\mathrm{p}<0.001)$. In addition, redness $\left(a^{*}\right)$ in the $100 \mathrm{mg} / \mathrm{kg} \beta$-carotene treatment group was significantly lower compared with the 100 $\mathrm{mg} / \mathrm{kg}$ Lutein Beads and $25 \mathrm{mg} / \mathrm{kg}$ canthaxanthin treatment groups (Table 8 ).

As shown in Table 9, breast and leg skin and meat yellowness $\left(b^{*}\right)$ in the $100 \mathrm{mg} / \mathrm{kg}$ Lutein Beads, 25 $\mathrm{mg} / \mathrm{kg}$ apo-ester and $25 \mathrm{mg} / \mathrm{kg}$ Xamaco|ß groups were significantly higher than those in the control, $100 \mathrm{mg} / \mathrm{kg}$ Lyco Beads and $100 \mathrm{mg} / \mathrm{kg} \beta$-carotene groups ( $p>0.05$ ). No differences were found between the breast and leg skin and meat yellowness $\left(b^{*}\right)$ of the control, $100 \mathrm{mg} / \mathrm{kg}$ Lyco Beads and $100 \mathrm{mg} / \mathrm{kg}$ $\beta$-carotene groups ( $p>0.05$ ). Although canthaxanthin is a pigment that is used to enhance redness, it also significantly increased meat and skin yellowness $\left(b^{*}\right)$ in the broilers that received it as a supplement compared with the control broilers. By contrast, meat and skin yellowness was negatively affected in the $200 \mathrm{mg} / \mathrm{kg}$ vitamin E supplemented group and was similar to that of the control group.

Breast and leg skin and meat lightness $\left(L^{*}\right)$ were significantly improved in the canthaxanthin treatment group compared with the other treatment groups (see Table 10).

\section{DISCUSSION}

\section{Performance}

Compared with the corn-and soybean-based control diet, the supplementation with selenium, vitamin $\mathrm{E}$ and carotenoids from various sources did not cause any significant differences in the live weight, feed intake

Table $\mathbf{8}$ - The effects of different sources of antioxidants on skin and meat pigmentation redness $\left(a^{*}\right), n=6$

\begin{tabular}{|c|c|c|c|c|}
\hline \multirow{2}{*}{ Treatments } & \multicolumn{2}{|c|}{ Skin } & \multicolumn{2}{|c|}{ Meat } \\
\hline & breast & Leg & breast & leg \\
\hline Control (Cont) & $1.00 \pm 0.45^{b}$ & $0.01 \pm 0.42^{\mathrm{cb}}$ & $-1.70 \pm 0.14^{b}$ & $1.49 \pm 0.57^{b}$ \\
\hline Cont+0.5 Sel-Plex & $1.94 \pm 0.54^{b}$ & $-0.05 \pm 0.32^{\mathrm{cb}}$ & $-1.07 \pm 0.76^{b}$ & $1.71 \pm 0.94^{b}$ \\
\hline Cont+200 Vitamin E & $1.60 \pm 1.28^{b}$ & $-0.58 \pm 0.63^{c b}$ & $-1.06 \pm 0.62^{b}$ & $1.16 \pm 0.47^{b}$ \\
\hline Cont+100 Lutein Beads & $1.861 \pm 0.41^{b}$ & $1.39 \pm 0.63^{b}$ & $-0.01 \pm 0.22^{b}$ & $2.69 \pm 0.48^{b}$ \\
\hline Cont+100 Lyco Beads & $1.44 \pm 0.97^{b}$ & $0.85 \pm 1.05^{\mathrm{cb}}$ & $-1.00 \pm 0.32^{b}$ & $2.26 \pm 1.36^{b}$ \\
\hline Cont+25 Canthaxanthin & $8.92 \pm 0.95^{a}$ & $4.20 \pm 0.70^{\mathrm{a}}$ & $6.57 \pm 0.72^{\mathrm{a}}$ & $8.38 \pm 0.72^{\mathrm{a}}$ \\
\hline Cont+25 Apo-ester & $3.93 \pm 1.48^{b}$ & $0.77 \pm 0.45^{c b}$ & $0.36 \pm 0.51^{b}$ & $1.55 \pm 0.71^{b}$ \\
\hline Cont+25 Xamacol & $3.65 \pm 1.86^{b}$ & $0.52 \pm 0.77^{c b}$ & $-0.45 \pm 0.54^{b}$ & $2.43 \pm 0.71^{b}$ \\
\hline Cont+100 $\otimes$-carotene & $0.92 \pm 0.80^{b}$ & $-0.83 \pm 0.48$ & $-0.09 \pm 1.19^{b}$ & $0.33 \pm 0.62^{b}$ \\
\hline $\mathrm{F}$ & 5.86 & 5.12 & 15.30 & 9.08 \\
\hline$P$ & $<.0001$ & $<.0002$ & $<.0001$ & $<.0001$ \\
\hline
\end{tabular}

$a-b$ are used to indicate that within the same column, the valuesthat donot share a common superscript are significantly different at the level of probability indicated. 
Table 9 - The effects of different sources of antioxidants on skin and meat pigmentation yellowness $\left(b^{*}\right)$ values, $n=6$

\begin{tabular}{|c|c|c|c|c|}
\hline \multirow{2}{*}{ Groups } & \multicolumn{2}{|r|}{ Skin color } & \multicolumn{2}{|c|}{ Meat color } \\
\hline & breast & leg & breast & leg \\
\hline Control (Cont) & $12.93 \pm 0.51^{\mathrm{cd}}$ & $11.65 \pm 0.64^{c}$ & $9.49 \pm 0.55^{d}$ & $8.87 \pm 0.42^{\mathrm{ed}}$ \\
\hline Cont+0.5 Sel-Plex & $13.91 \pm 0.46^{\mathrm{cd}}$ & $11.92 \pm 0.61^{c}$ & $11.19 \pm 0.88^{d c}$ & $11.11 \pm 1.68^{\mathrm{ed}}$ \\
\hline Cont+200 Vitamin E & $12.29 \pm 0.52^{d}$ & $9.34 \pm 0.39^{d}$ & $10.24 \pm 0.76^{d c}$ & $9.98 \pm 0.62^{\text {ed }}$ \\
\hline Cont+100 Lutein Beads & $21.95 \pm 0.59^{a}$ & $19.96 \pm 0.81^{\mathrm{a}}$ & $17.88 \pm 0.83^{a}$ & $17.65 \pm 0.65^{a}$ \\
\hline Cont+100 Lyco Beads & $15.01 \pm 1.32^{\mathrm{cbd}}$ & $14.72 \pm 0.83^{b}$ & $12.37 \pm 0.61^{c}$ & $11.45 \pm 0.62^{\mathrm{cd}}$ \\
\hline Cont+25 Canthaxanthin & $22.59 \pm 1.73^{\mathrm{a}}$ & $15.94 \pm 1.07^{b}$ & $16.76 \pm 1.03^{\text {ba }}$ & $15.01 \pm 0.88^{b}$ \\
\hline Cont+25 Apo-ester & $20.71 \pm 0.82^{\mathrm{a}}$ & $16.33 \pm 0.74^{b}$ & $15.03 \pm 0.98^{b}$ & $14.97 \pm 1.27^{b}$ \\
\hline Cont+25 Xamacol & $17.42 \pm 0.74^{b}$ & $14.91 \pm 0.73^{b}$ & $14.75 \pm 1.24^{b}$ & $12.63 \pm 1.66^{\mathrm{cb}}$ \\
\hline Cont+100 $\beta$-carotene & $15.37 \pm 0.78^{\mathrm{cb}}$ & $10.06 \pm 0.55^{c}$ & $12.48 \pm 0.34^{c}$ & $8.70 \pm 0.90^{e}$ \\
\hline $\mathrm{F}$ & 18.34 & 18.17 & 15.16 & 14.03 \\
\hline $\mathrm{p}<$ & 0.00012 & 0.00019 & 0.00021 & 0.00049 \\
\hline
\end{tabular}

a-e are used to indicate that within the same column, the values that donot share a common superscript are significantly different at the level of probability indicated.

or feed conversion ratio (FCR) over the course of the 6 -week experimental period ( $p>0.05$ ).

Our findings for selenium are in line with those of Selle et al. (2013); Tayeb \& Qader (2012); Skrivan et al. (2008), who reported that different doses of selenium and vitamin $E$ had no significant effects on live body weight, body weight gain, feed intake, or FCR. Our findings for Se were not in agreement with those of Hoffman (2007); Ozkan et al. (2007) or Zelenka \& Fajmonova (2005), who noted that the FCR of broilers fed organic Se supplements was improved compared with that of broilers fed un-supplemented diets.

Our findings for vitamin E supplementation are in agreement with those of Bottje et al. (1997); Rama Rao et al. (2011) who reported that differences in dietary $\alpha$-tocopheryl acetate concentrations $(0,17,46$ and $87 \mathrm{mg} / \mathrm{kg}$ diet) had no effect on broiler performance. By contrast, Chae et al. (2006) and Rebole et al. (2006) reported that supplementation of $200 \mathrm{mg} / \mathrm{kg}$ $\alpha$-tocopheryl acetate increased body weight gain and the FCR without affecting feed intake.
Pigment supplementation has previously been reported to have no significant effect on feed intake or body weight (Fletcher et al., 1986; Haq et al. 1995, 1996; Royle et al. 1999; Jensen et al. 1998; PerezVendrell et al., 2001; Fenoglio et al. 2002; Waldenstedt et al. 2003; Castañeda et al., 2005; Li et al., 2012).

In contrast with the above performance parameters, our study found that the mortality rate was significantly affected by antioxidant supplementation. The mortality rate of the group that received supplementary $\beta$-carotene was significantly higher than those of the $200 \mathrm{mg} / \mathrm{kg}$ vitamin E, $100 \mathrm{mg} / \mathrm{kg}$ Lutein Beads, $25 \mathrm{mg} / \mathrm{kg}$ canthaxanthin and $25 \mathrm{mg} / \mathrm{kg}$ Xamaco $^{\circledR}$ groups. These differences may have been caused by differences in the dosages. Our results are in line with those of Siegel et al. (2000), who reported day 41 mortality rates of $8.6 \% 7.5 \%$ and $5.4 \%$ for chickens that received dietary vitamin $\mathrm{E}$ supplementation of 10,100 , and $300 \mathrm{IU} / \mathrm{kg}$ per day, respectively. Similarly, Blum et al. (1992) reported an increased mortality rate in cocks and hens that received a low level of

Table 10 - The effects of different sources of antioxidants on skin and meat lightness $\left(L^{*}\right)$ values, $n=6$

\begin{tabular}{lllll}
\hline Treatments & \multicolumn{2}{c}{ Skin color } & Meat color \\
\cline { 2 - 5 } & breast & leg & breast & leg \\
\hline Control (Cont) & $65.30 \pm 1.19^{\mathrm{a}}$ & $64.12 \pm 1.31^{\mathrm{a}}$ & $56.13 \pm 1.34^{\mathrm{a}}$ & $55.84 \pm 0.97^{\mathrm{a}}$ \\
Cont+0.5 Sel-Plex & $64.96 \pm 1.12^{\mathrm{a}}$ & $64.21 \pm 0.85^{\mathrm{a}}$ & $56.95 \pm 1.04^{\mathrm{a}}$ & $56.85 \pm 1.92^{\mathrm{a}}$ \\
Cont+200 Vitamin E & $64.54 \pm 0.72^{\mathrm{a}}$ & $63.85 \pm 0.88^{\mathrm{a}}$ & $56.77 \pm 0.59^{\mathrm{a}}$ & $56.05 \pm 1.04^{\mathrm{a}}$ \\
Cont+100 Lutein Beads & $64.46 \pm 0.89^{\mathrm{a}}$ & $64.00 \pm 0.64^{\mathrm{a}}$ & $56.98 \pm 0.93^{\mathrm{a}}$ & $54.90 \pm 1.19^{\mathrm{a}}$ \\
Cont+100 Lyco Beads & $64.24 \pm 0.07^{\mathrm{a}}$ & $64.72 \pm 1.09^{\mathrm{a}}$ & $56.61 \pm 1.97^{\mathrm{a}}$ & $55.70 \pm 1.15^{\mathrm{a}}$ \\
Cont+25 Canthaxanthin & $57.72 \pm 0.59^{\mathrm{b}}$ & $58.51 \pm 1.07^{\mathrm{b}}$ & $47.84 \pm 0.36^{\mathrm{b}}$ & $46.62 \pm 0.54^{\mathrm{b}}$ \\
Cont+25 Apo-ester & $63.95 \pm 0.83^{\mathrm{a}}$ & $64.18 \pm 0.75^{\mathrm{a}}$ & $55.33 \pm 1.41^{\mathrm{a}}$ & $55.79 \pm 1.34^{\mathrm{a}}$ \\
Cont+25 Xamacol & $64.17 \pm 1.00^{\mathrm{a}}$ & $64.74 \pm 0.72^{\mathrm{a}}$ & $56.81 \pm 0.70^{\mathrm{a}}$ & $53.59 \pm 1.52^{\mathrm{a}}$ \\
Cont+100 $\beta$-carotene & $63.95 \pm 1.06^{\mathrm{a}}$ & $64.29 \pm 0.33^{\mathrm{a}}$ & $54.15 \pm 1.37^{\mathrm{a}}$ & $53.05 \pm 1.18^{\mathrm{a}}$ \\
\hline F & 6.17 & 4.62 & 6.33 & 6.80 \\
\hline P & 0.0001 & 0.0004 & 0.0001 & 0.0001 \\
\hline
\end{tabular}

$a-b$ are used to indicate that within the same column, the values that donot share a common superscript are significantly different at the level of probability indicated. 
vitamin E supplementation (20 mg/kg diet) $(3.2 \%$ and $2.9 \%$, respectively) compared with that of hens that received a higher (160 mg vitamin E/kg diet) level, for which the mortality rates decreased $(1.7 \%$ and $1.5 \%$, respectively). In other previous animal studies, the survival rates of parrot fish larvae were found to increase with $\beta$-carotene supplementation (Tachibana et al. 1997), and lycopene was shown to enhance mouse resistance to bacterial infection with Klebsiella pneumoniae (Lingen et al. 1959). However, in our study, $\beta$-carotene and lycopene supplementation did not improve survival rates.

\section{Immune response}

The immune responses of the birds were significantly stimulated by all experimental treatments compared with those in the unvaccinated controls. Interestingly, immunity was significantly higher in the vaccinated controls compared with the unvaccinated controls $(p<0.05)$, and there were no differences in immune stimulation between the vaccinated control group and the birds fed the Xamacol $($ - and $\beta$-carotenesupplemented diets. It is possible that HI was stimulated by both treatments on day 14 prior to vaccination, which could account for these results. Newcastle disease challenges are often used to assess the immunestimulating properties of antioxidants. Surai (2006) reported that Se and vitamin E significantly improved the immune responses of chicks vaccinated with a live Newcastle vaccine. Shekaro et al. (2012) have reported that the addition of $0.5 \mathrm{ppm}$ organic Se to broiler diets enhanced the immune response against infectious bursal disease, and a number of other studies (El- Sheik et al., 2010; Erf et al., 1998; Arshad et al.2005; Hegazy \& Adachi, 2000; Denghua et al., 2001; Ez-Vendrell et al., 2001) have found that humoral antibody titers increase when feed is supplemented with Se or vitamin E. Our findings that organic selenium supplements (0.5 ppm) significantly increased the 10-day postvaccination $\mathrm{HI}$ antibody titers against NDV (compared with both the unvaccinated and vaccinated controls, as well as the birds given 25 ppm Xamacol ${ }^{\circledR}$ supplements $(p<0.05)$, are in agreement with the findings of the studies mentioned above.

In our study, dietary supplementation with 200 mg/ $\mathrm{kg} \alpha$-tocopherol significantly increased the antibody response to the NDV vaccine compared with the response in both the unvaccinated and vaccinated controls, as well as that of the broilers given $25 \mathrm{ppm}$ Xamacol $^{\circledR}(p<0.05)$. These results are in line with those of a number of studies (Boa-Amponsem et al.,
2006; Leshchinky \& Klasing, 2001) that have reported significant increases in the humoral immune responses of chickens provided with higher concentrations of dietary $\alpha$-tocopherols $(200-300 \mathrm{mg} / \mathrm{kg})$. By contrast, Rama Rao et al. (2011) reported that $\alpha$-tocopherol $(<100 \mathrm{mg} / \mathrm{kg}$ ) had no significant effect on the humoral immune response to NDV, and Marsh et al. (1981) and Qureshi et al. (1993) reported a similar lack of an effect of dietary supplementation with higher levels of $\alpha$-tocopherol (100-250 mg/kg).

Links between immune function and carotenoids have been experimentally demonstrated (Penissi 2003; Blount et al., 2003; Moller et al., 2000; Camplani et al., 1999; McGraw\&Ardia2003; McGraw et al. 2006; Aguilera \& Amat, 2007; Fitze et al., 2007; AlonsoAlvarez et al., 2004; Schiedt et al., 1985; Sepp et al., 2011). Our results are in agreement with those of several studies (Tengerdy et al., 1990; Cheng et al., 2001; Cucco et al., 2006) that have demonstrated that $\beta$-carotene does not effectively protect chickens against E.coli or enhance antibody protection; however, our findings conflict with those of Bendich \& Shapiro (1986) and Jyonouchi et al. (1994), who have reported that $\beta$-carotene enhances the immune response in rats. Our findings of the positive effects of other carotenes on the immune system are in line with previous findings indicating that carotenoids have immune-suppressive effects in bird species (Fenoglio et al., 2002; Koutsos et al., 2003a,b; Tengerdy et al., 1990; Blount et al., 2003; Pennisi, 2003; Moller et al, 2000; Peters et al., 2004; Klasing, 2007).

\section{Plasma carotene concentrations}

With the optimum level of carotenoid supplementation of broiler diets, the degree of carotene accumulation varied according to the supplement provided as follows: Xamacol ${ }^{\circledR}>$ canthaxanthin $>$ apoester>vitamin $\mathrm{E}>$ selenium $>$ control $(p<0.05)$ (Table5).

The significant increases in the plasma total carotenoid concentrations that were observed when the basal diet was supplemented with pigments, as well as with vitamin $\mathrm{E}$ and $\mathrm{Se}$, demonstrated the synergistic effects of substances with antioxidant properties. However, unlike the optimum level of carotenoid supplementation $(25 \mathrm{mg} / \mathrm{kg}$ ) in the control diet, Table 5 shows that the total carotenoid accumulation in the plasma of the chickens was only increased by dietary supplementation with $100 \mu \mathrm{g} / \mathrm{kg}$ Lutein Beads and not by high-dose $(100 \mu \mathrm{g} / \mathrm{kg}$ diet $)$ carotenoid supplementation (except for the first week over the course of the experiment) compared with that in the control group. 
As shown in (Table 5). Lyco Beads and $\beta$-carotene had no significant effects on the total plasma carotene concentrations ( $p>0.05)$. Further research is necessary to explore the differences related to the chemical compositions of lycopene, lutein and $\beta$-carotene.

Table 5 shows that the best results for total plasma carotenoid accumulation were obtained with supplementation of $25 \mathrm{mg} / \mathrm{kg}$ Xamacol${ }^{\circledR}$, followed by $25 \mathrm{mg} / \mathrm{kg}$ canthaxanthin, $25 \mathrm{mg} / \mathrm{kg}$ apo-ester, 100 $\mathrm{mg} / \mathrm{kg}$ Lutein Beads and $100 \mathrm{mg} / \mathrm{kg} \beta$-carotene. These results, which suggest that quality is more important than quantity, are not in agreement with those of Sepp et al. (2011), who have shown that differences in carotenoid supplement dosages do not significantly affect plasma carotenoid levels. The low level of plasma carotenoid accumulation found with high doses of supplementary $\beta$-carotene in our study might indicate pro-oxidant activity, which would supports the findings of Ruiz et al. (1999), who observed antioxidant activity in both the fresh and cooked meat of broilers that were fed diets containing $15 \mathrm{ppm} \beta$-carotene and found pro-oxidant activity when the amount was increased to $50 \mathrm{ppm}$. In a study of rats, Alam \& Alam (1983) found that plasma and liver peroxide levels increased as the dose of $\beta$-carotene increased, but no beneficial effects were observed. Similar data were reported by Lomnitski et al. (1991), who described increases in testes TBARS values as a result of $\beta$-carotene dietary supplementation.

Lutein is a carotenoid that constitutes major parts of the avian diet, egg yolk and tissue. It has also been shown to perform better than $\beta$-carotene in quenching lipid peroxyl radicals and to be a more efficient antioxidant than $\alpha$-tocopherol in vitro (Chopra et al., 1993). Woodall et al. (1996) reported that 37-dayold chickens provided with dietary supplementation of $100 \mathrm{mg} / \mathrm{kg}$ of either $\beta$-carotene, zeaxanthin, or canthaxanthin had total plasma carotene levels of 3.3, 15.5 , and $7.1 \mu \mathrm{g} / \mathrm{mL}$, respectively, compared with the level of only $2.6 \mu \mathrm{g} / \mathrm{mL}$ that was found in birds fed a commercial diet with no supplements. Their results for $\beta$-carotene are very similar to ours, but their findings for canthaxanthin are different than ours $(8.18 \pm 1.26$ $\mu \mathrm{g} / \mathrm{mL}$ with $25 \mathrm{mg} / \mathrm{kg}$ dietary supplementation). Our findings also showed that Lutein Beads were more efficient than Lyco Beads in transferring dietary carotenoids to the plasma. These results are consistent with previous observations that have indicated that lycopene is much less efficient than other carotenoids in terms of egg yolk deposition (Karadas et al., 2006). Sikder et al. (1998) has attributed these differences to the different characteristics of the various types of carotenoids. A previously published lycopene doseresponse study has demonstrated the saturation of lycopene absorption at increasing doses (DiwadkarNavsariwala et al., 2004). Increasing serving sizes of a tomato beverage were administered to adult men; these servings delivered lycopene doses ranging from 10 to $120 \mathrm{mg}$. Compartmental modeling showed that the lycopene absorption rates for 10,30, and 60 mg were 34,14 , and $7 \%$, respectively (Novotny et al., 2010). In our study, we found that over the dose range studied, absorption efficiencies decreased with increasing dose.

Studies have revealed much higher carotenoid concentrations in the plasma of wild birds (Surai,2002). For example, Tella et al. (1998) investigated plasma carotenoid concentrations in 356 birds from 26 wild species and found concentrations ranging from 0.4 to $74.2 \mu \mathrm{g} / \mathrm{mL}$, with an average concentration of $9.4 \mu \mathrm{g} /$ $\mathrm{mL}$. The plasma carotenoid concentrations in white storks were shown to increase from $2.2 \mu \mathrm{g} / \mathrm{mL}$ to 11.1 $\mu \mathrm{g} / \mathrm{mL}$ after they were fed a diet of crayfish (Negro et al., 2000). Plasma carotenoid concentrations in wild American Kestrels raised in captivity were found to vary from approximately 4 to $87 \mu \mathrm{g} / \mathrm{mL}$, depending on the season and bird sex and age (Negro et al., 1998). Plasma carotenoid concentrations in wild shrikes were found to vary from approximately 10 to $20 \mu \mathrm{g} / \mathrm{mL}$ (Bortolotti et al., 1996). Unlike those in the wild birds, the plasma total carotenoid accumulation for the broilers in our study did not exceed $16 \mu \mathrm{g} / \mathrm{mL}$, regardless of the dose of supplementary carotenoid. Further research should be conducted to better elucidate the effects of dosage.

\section{Liver antioxidant (total carotenoid, vitamin $E_{\text {, and coenzyme }} \mathbf{Q}_{\mathbf{1 0}}$ ) concentrations}

The liver is considered the main storage site for fatsoluble antioxidants (carotenoids, vitamins A, E and coenzyme $Q_{10}$ ) (Tyczkowski \& Hamilton, 1986; Schiedt, 1998, Galvan et al., 2012). The analysis of bird livers performed in the present study showed that the total carotenoid levels in the livers of the birds that received carotenoid dietary supplements were significantly higher than those in the controls $(p<0.05)$ (Table 6). The total liver carotenoid levels in the canthaxanthin treatment group were also significantly higher than those in the Lutein Bead and Lyco Bead treatment groups $(p<0.05)$. The finding that canthaxanthin accumulates at higher rates than other synthetic red pigments is consistent with reports in the literature (Klasing, 1998; Waldenstedt et al., 2003). 
Vitamin E supplementation was found to significantly increase the liver vitamin $E$ concentrations $(p<0.05)$; however, the different antioxidant treatments did not significantly affect the liver coenzyme $\mathrm{Q}_{10}$ levels (Table 6).

The dietary supplements did not significantly affect the liver retinol levels, but they did have significant effects on the liver retinol ester concentrations $(p<0.05)$ (Table 7). The supplementation with $\beta$-carotenoid significantly increased the liver R-linoleate and R-oleate concentrations, whereas all of the other treatments significantly decreased the R-oleate concentrations compared with that in the control group. With the exception of $\beta$-carotenoid, all of the other dietary supplements decreased liver R-palmitate concentrations compared with that in the control group. Compared with the concentrations in the controls, both apoester and $\beta$-carotenoid supplementation significantly increased the R-stearate concentrations, which, however, were not affected by the other experimental treatments. Moreover, the R-stearate concentrations in the $\beta$-carotenoid treatment group were higher than those in the apo-ester treatment group. The total vitamin A concentration was significantly higher in the $\beta$-carotenoid treatment group, whereas the concentrations were significantly lower in all of the other treatment groups compared with the control group, with the exception of the apo-ester treatment group.

These results are in accordance with reports in the literature and indicate that rather than influencing skin pigmentation, $\beta$-carotene, which is a precursor of vitamin $A$, tends to be converted into retinoids (Barua \& Olson 2000; Poor et al., 1987), which mainly accumulate in tissues as oxy-carotenoids (Surai, 2002). A study conducted by Yeum \& Russell (2002) has demonstrated that orally administered physiological doses of $\beta$-carotene are completely converted into vitamin $A$ in the small intestine enterocytes of rats, producing retinoid forms that are incorporated into chylomicrons, secreted into lymph, injected into the blood stream and then delivered to the liver for storage. The direct measurement of liver vitamin A reserves has been described as the gold standard for assessing vitamin A status (Barua \& Olson, 2000;Tanumihardjo, 2004; Howe \& Tanumihardjo, 2006). However, it has been suggested that the dose may influence the conversion of $\beta$-carotene to vitamin A (Brubacher \& Weiser 1985).

\section{Skin and meat pigmentation}

Whether consumers consider a product attractive will influence their purchasing decisions. The color of raw poultry meat is important in terms of consumer expectations regarding freshness; raw breast meat is expected to be pale pink in color, and raw thigh and leg meat is expected to be dark red (Northcutt, 2009).

\section{Redness (a* values)}

Our study found that supplementation of broiler diets with canthaxanthin significantly improved breast and leg skin and meat redness ( $\left.a^{*}\right)$ (Table 8$)$. The leg skin pigmentation $a^{*}$ values in the canthaxanthin treatment group were higher than those in the other treatment groups. However, the $a^{*}$ values in the $\beta$-carotene group were lower than those in both the canthaxanthin and Lutein Bead groups. It is possible that rather than contributing to pigmentation, the majority of $\beta$-carotenoid accumulated in the liver as retinol and retinol esters, which would explain these findings.

Canthaxanthin is commonly used to provide a yellowish-reddish color to broiler carcasses (PérezVendrell et al., 2001), which is an important factor for consumer acceptance in various countries (Castaneda et al., 2005; Liu et al., 2008). The commercial poultry industry considers an $a^{*}$ value of at least 4 to be desirable (Castaneda et al., 2005). Castaneda et al. (2005), who investigated the effects of different pigment types and amounts in broiler diets, reported that a synthetic pigment provided results closest to the commercially prescribed a* value. The canthaxanthin-supplemented group in our study not only met this goal but also had close to twice the minimum recommended commercial a* value.

Tyczkowski \& Hamilton (1986) studied the absorption, transport and deposition of canthaxanthinin broilers that were provided with dietary supplements ranging from $5-80 \mathrm{mg} / \mathrm{kg}$ feed and found that the canthaxanthin concentrations in the jejunum, large intestine, serum, liver and toe web were directly proportional to those provided in the diet. Our study used the level of canthaxanthin recommended for broiler diets $(25 \mathrm{mg} / \mathrm{kg})$ and obtained significant improvements in skin and meat redness values $(p<0.05)$.

Canthaxanthin has been reported to accumulate in the tissue and eggs of wild birds such as mallards and gulls (McGraw \& Toomey 2010; Surai et al., 2001b; Prager et al., 2009; Surai, 2012), and commercial broiler producers should take this into consideration when contemplating the canthaxanthin supplementation of broiler diets.

\section{Yellowness ( $b$ * values)}

The present study found $b$ * values ranging from 1 to 9 (Table 9). Bianchi et al. (2005) reported yellowness 
$\left(b^{*}\right)$ values of 6.2 for normal breast meat and 7.6 for pale breast meat. Castroman et al. (2013) reported breast meat and leg meat yellowness values of 16.9 and 16.7, respectively, for organic broilers and 19.7 and 19.1, respectively, for conventional broilers. Although our values are higher than those reported by Bianchi et al. (2005), they are very close to those reported by Castroman et al. (2013) and other studies in the literature (Waldenstedt et al., 2003; Inborr \& Lignell, 1997). Yellowness in breast skin is a good indicator of the xanthophyll content in feed (Pérez-Vendrell et al., 2001), with more intense yellow tones of broiler carcasses suggesting a higher intake of yellow pigments from through the diet (Mourao et al., 2008).

\section{Lightness ( $L *$ values)}

At 24 hours post-mortem, the $L^{*}$ values in the group that received supplementary canthaxanthin $\left(L^{*}=46-47\right)$ were significantly lower than those in all of the other experimental groups in our study (Table 10). The findings for these groups $\left(L^{*}=54-56\right)$ are in line with the values $\left(L^{*}=53-57\right)$ reported by Castromán et al. (2013). Although Van Laack et al. (2000) used an $L^{*}$ value of 60 as the limit for pale poultry breast meat, other studies (Petracci et al., 2004; Bianchi et al., 2005; Castromán et al., 2013) used an L* value of 53 as a cut-off to distinguish between pale and normal poultry meat. Accordingly, the values found in the present study would be considered pale, with the exception of the canthaxanthin group, for which the values would be considered normal.

\section{CONCLUSIONS}

The present study showed that supplementation of commercial broiler diets with antioxidants significantly improved the immune response and liver antioxidant concentrations. Carotenoids were also found to improve skin and meat pigmentation. Total plasma carotenoid levels were also improved by Se and vitamin E supplementation, indicating the synergic effects of antioxidants. However, the fact that high doses of $\beta$-carotene also increased mortality rates must be considered.

\section{ACKNOWLEDGEMENTS}

This study received support from the office of the Yüzüncü YIl University President's Scientific Research Project Fund (Grant No:2007-ZF-B119). The authors also thank the following sources for providing the materials used in this study: DSM (10\% Carophyll ${ }^{\circledR}$ Red,
$10 \%$ Carophyl| ${ }^{\circledR}$ Yellow, and 10\% Rovimix ${ }^{\circledR} \beta$-carotene); Kartal Chemical (vitamin E); Alltech (Sel-plex); LycoRed (5\% Lutein Beads XB and 5\% Lyco Beads XB); and Novus International (Tagetes erecta). The authors also like to thank Aimee Talarskib (American Journal Experts) and Deborah Semel Demirtaş for editing this manuscript.

\section{REFERENCES}

Aguilera E, Amat J. Carotenoids, immune response and the expression of sexual ornaments in male greenfinches (Carduelis chloris). Naturwissenschaften 2007;94:895-902

Alam SQ, Alam BS. Lipid peroxide, alpha-tocopherol and retinoid levels in plasma and liver of rats fed diets containing beta-carotene and 13-cisretinoic acid. Journal of Nutrition 1983:113:2608-2614.

Alonso-Alvarez C, Bertrand S, Devey G, Gaillard M, Prost J, Faivre B, Sorci G. An experimental test of the dose-dependent effect of carotenoids and immune activation on sexual signals and antioxidant activity. American Naturalist 2004;164:651-659.

Arshad M, Siddique M, Ashaf M, Khan HA. Effects of supplementation on antibody titers against infections bursal disease vaccine in broiler chicks. Pakistani Veterinary Journal 2005;25(4):203-204.

Barua $A B$, Olson JA. Beta-carotene is converted primarily to retinoids in rats in vivo. Journal of Nutrition 2000;30:1996-2001.

Bendich A, Shapiro SS. Effect of beta-carotene and canthaxanthin on the immune responses of the rat. The Journal of Nutrition 1986;116:22542262.

Bianchi M, Fletcher DL, Smith DP. Physical and functional properties of intact and ground pale broiler breast meat. Poultry Science 2005;84:803-808.

Biard C, Surai PF, Møller AP. Effects of carotenoid availability during laying on reproduction in the blue tit. Oecologia 2005;144:32-44

Blount JD, Metcalfe NB, Birkhead TR, Surai PF. Carotenoid Modulation of immune function and sexual attractiveness in zebra finches. Science 2003:300:125-127

Blum JC, Touraille C, Salichon, MR, Ricard FH, Frigg M. Effect of dietary vitamin E supplies in broilers. 2. Male and female growth rate, viability, immune response, fat content and meat flavour variations during storage. Archive fur Geflugelkunde 1992;56:37-42.

Boa-Amponsem K, Picard M, Blair ME, Meldrum B, Siegel PB. Memory antibody responses of broiler and Leghorn chickens as influenced by dietary vitamin $\mathrm{E}$ and route of sheep red blood cell administration. Poultry Science 2006;85:173-177.

Bortolotti GR, Negro JJ, Tella JL, Marchant TA, Bird DM. Sexual dichromatism in birds independent of the diet, parasites and androgens. Proceedings of the Royal Society 1996;263:1171-1176.

Bottje WG, Erf GF, Bersi TK, Wang S, Barnes D, Beers KW. Effect of dietary d-alpha-tocopherol on tissue alpha- and gamma-tocopherol and pulmonary hypertension syndrome (ascites) in broilers. Poultry Science 1997:76:1506-1512.

Brubacher GB, Weiser $\mathrm{H}$. The vitamin A activity of B-carotene. International Journal for Vitamin and Nutrition Research 1985;55:5-15.

Camplani A, Saino N, Møller AP. Carotenoids, sexual signals and immune function in barn swallows from Chernobyl. Proceedings of the Royal Society of London B 1999:266:1111-1116. 
Castañeda MP, Hirschler EM, Sams AR. Skin pigmentation evaluation in broilers fed natural and synthetic pigments. Poultry Science 2005;84:143-147.

Castromán G, Del Puerto M, Ramos A, Cabrera MC, Saadoun A. Organic and conventional chicken meat produced in Uruguay: colour, $\mathrm{pH}$, fatty acids composition and oxidative status. American Journal of Food and Nutrition 2013;1(2):12-21

Chae BJ, Lohakare JD, Choi JY. Effects of incremental level of $\alpha$-tocopheryl acetate on performance, nutrient digestibility and meat quality of commercial broilers. Asian-Australasian Journal of Animal Science 2006;19:203-208.

Cheng YH, Shen TF, Pang VF, Chen BJ. Effects of aflatoxin and carotenoids on growth performance and immune response in mule ducklings. Comparative Biochemistry and Physiology C 2001;128:19-26.

Chopra M, Willson RL, Thurnham DI. Free radical scavenging activity of lutein in vitro. York Academy of Sciences 1993;691(1):246-249.

Colnago GL, Jensen LS, Long PL. Effect of selenium and vitamin $E$ on the development of immunity to coccidiosis in chickens. Poultry Science 1984;63:1136-1143.

Costantini D, Møller AP. Carotenoids are minor antioxidants for birds. Functional Ecology 2008;22:367-370.

Cucco M, Guasco B, Malacarne G, Ottonelli R. Effects of beta-carotene supplementation on chick growth, immune status and behavior in the grey partridge, Perdix perdix. Behavioral Processes 2006;73:325-332.

Denghua YH, Yuqing L, Yong M. Effects of immune enhancement with selenium on immune function in chickens. Chinese Journal of Veterinary Science $2001 ; 21: 96-98$

Diwadkar-Navsariwala V, Novotny JA, Gustin DM, Sosman JA, Rodvold KA, Crowell JA, Stacewicz-Sapuntzakis M, Bowen PE. A physiological pharmacokinetic model describing the disposition of lycopene in healthy men. Journal of Lipid Research 2004;44:1927-1939.

El-Sheikh AMH, Abdalla EA, Maysa MH. The effect of organic selenium supplementation on productive and physiological performance in a local strain of chicken. Egyptian Poultry Science Journal 2010;30:517533.

Erf GF, Bottje WG, Bersi TG, Headrick MD, Fritts CA. Effect of dietary vitamin E. on the immune system in broilers: Altered proportions of CD4 T cells in the thymus and spleen. Poultry Science 1998;77:529-537.

Ez-Vendrell AM, Hernandez JM, Llaurado L, Schierle J, Brufau J. Influence of source and ratio of xanthophyll pigments on broiler chicken pigmentation and performance. Poultry Science 2001;80:320-326.

Fenoglio S, Cucco M, Malacarne G. The effect of a carotenoid-rich diet on immune competence and behavioral performances in Moorhen chicks. Journal of Evolutionary Biology 2002;14:149-156.

Fitze PS, Tschirren B, Gasparini J, Richner H. Carotenoid-based plumage colors and immune function: is there a trade-off for rare carotenoids? American Naturalist 2007;169:S137- S144.

Fletcher DL, Papa CM, Tirado FX. The effects of saponification on the broiler coloroing capability of marigold extract. Poultry Science 1986;65:17081714.

Galván I, Erritzøe J, Karadaş F, Møller AP. High levels of liver antioxidants are associated with life-history strategies characteristic of slow growth and high survival rates in birds. Journal of Comparative Physiology Part B 2012:182:947-959.

Goodwin TW. Carotenoids and reproduction. Biological Reviews 1950;25:391-413.
Haq AU, Bailey CA, Chinnah A. Effect of $\beta$-carotene, canthaxanthin, lutein and vitamin $E$ on neonatal immunity of chicks when supplemented in the broiler breeder diets. Poultry Science 1996;75:1092-1097.

Haq AU, Bailey CA, Chinnah A. Neonatal immune response and growth performance of chicks hatched from single comb White Leghorn breeders fed diets supplemented with beta-carotene, canthaxanthin or lutein. Poultry Science 1995;74:844-851.

Hegazy SM, Adachi Y. Comparison of the effects of dietary selenium and zinc supplementation on growth and immune response between chick groups that were inoculated with Salmonella and Aflatoxin. Poultry Science 2000;78:331-335.

Hoffmann, PR. Mechanisms by which selenium influences immune responses. Archivum Immunologiae et Therapia Experimentalis 2007:55:289-297.

Howe JA, Tanumihardjo SA. Evaluation of analytical methods for carotenoid extraction from biofortified maize (Zea mays sp.). Journal Agricultural Food Chemistry 2006;54:7992-7997.

Hoysak DJ, Weatherhead PJ. Sampling blood from birds: a technique and an assessment of its effect. Condor 1991;746-752.

Inborr J, Lignell Å. Effect of feeding astaxanthin-rich algae meal (Haematococcus pluvialis) on performance and carotenoid concentration of different tissues of broiler chickens. Proceedings of the 13th WPSA Conference on Poultry Meat Quality in Poznan; 1997 Sep 22-25; Poznan, Poland. Session M1, p.39-43.

Jensen C, Lauridsen C, Bertelsen G. Dietary vitamin E: quality and storage stability of pork and poultry. Trends in Food Science Technology 1998;9(2):62

Julseth, DR. Evaluation of vitamin E and disease stress in turkey performance [thesis]. Forth Collins (USA): Colorado State University; 1974.

Jyonouchi H, Zhang L, Gross M, Tomita Y. Immunomodulating actions of carotenoids: enhancement of in vivo and in vitro antibody production to T-dependent antigens. Nutrition and Cancer 1994;21:47-58.

Karadas F, Grammenidis E, Surai PF, Acamovic T, Sparks NHC. Effects of carotenoids from lucerne, marigold and tomato on egg yolk pigmentation and carotenoid composition. British Poultry Science 2006;47(5):561-566.

Karadas F, Surai PF, Sparks NH. Grammenidis E. Effects of maternal dietary supplementation with three sources of carotenoids on the retinyl esters of egg yolk and developing quail liver. British Poultry Science 2005a;47(2):200-208

Karadas F, Wood NAR, Surai PS, Sparks NHC. Tissue-specific distribution of carotenoids and vitamin $E$ in tissues of newly hatched chicks from various avian species. Comparative Biochemistry and Physiology Part A 2005b; 140:506-511.

Klasing KC. Comparative avian nutrition. London: Cab International; 1998.

Klasing KC. Nutrition and immune system. British Poultry Science 2007;48:525-537

Koutsos EA, Calvert CC, Humphrey BD, Klasing KC. Inter-actions between carotenoids and the inflammatory response in chickens. FASEB Journal 2003a;17:A1125-A11125.

Koutsos EA, Clifford AJ, Calvert CC, Klasing KC. Maternal carotenoid status modifies the incorporation of dietary carotenoids into immune tissues of growing chickens (Gallus gallus domesticus). Journal of Nutrition 2003b;133(4):1132-1138.

Kurien BT, Scofield RH. Autoimmunity and oxidatively modived auto antigens. Autoimmune Review 2008;7:567-573. 
Leshchinsky TV, Klasing KC. Relationship between the level of dietary vitamin $\mathrm{E}$ and the immune response of broiler chickens. Poultry Science 2001;80:1590-1599

Li H, Jin L, Wu F, Thacker P, Li X, You J, Wang X, Liu S, Li S, Xu Y. Effect of red pepper (Capsicum frutescens) powder or red pepper pigment on the performance and egg yolk color of laying hens. Asian Australasian Journal of Animal Sciences 2012;25(11): 1605-1610.

Lingen $C$, Ernster L, Lindberg $O$. The promoting effect of lycopene on the non-specific resistance of animals. Experimental Cell Research 1959;16:384-393.

Litta G, Chung TK, Weber GM. Vitamin E: vital for health and performance. Word Poultry 2014. Available from: http://www.worldpoultry.net/ Broilers Nutrition-2014 1437326.

Liu GD, Hou GY, Wang SJ, Lv SJ, Zhang XY, Sun WP, Yang Y. Skin pigmentation evaluation in broilers fed different levels of natural okra and synthetic pigments. Journal of Applied Poultry Research 2008;17:498-504.

Lomnitski L, Bergman M, Schon I, Grossman S. The effect of dietary vitamin $\mathrm{E}$ and beta-carotene on oxidation processes in the rat testis. Biochimica et Biophysica Acta 1991;1082(1):101-107.

Marsh JA, Dietert RR, Combs GF. Influence of dietary selenium and vitamin $E$ on the humoral immune response of the chick. Proceedings of the Society for Experimental Biology and Medicine 1981;166:228-236.

Mattila P, Kumpulainen J. Coenzymes Q(9) and Q(10): contents in foods and dietary intake. Journal of Food Composition and Analysis 2001;14(4):409-417.

McGraw KJ, Ardia DR. Carotenoids, immune competence, and the information content of sexual colors: An experimental test. American Naturalist 2003;162:704-712.

McGraw KJ, Crino OL, Medina-Jerez W, Nolan PM. Effect of dietary carotenoid supplementation on food intake and immune function in a songbird with no carotenoid coloration. Ethology 2006;112(12):12091216

McGraw KJ, Toomey MB. Carotenoid accumulation in the tissues of zebra finches: predictors of integumentary pigmentation and implications for carotenoid allocation strategies. Physiology and Biochemical Zoology 2010;83(1):97-109.

Møller AP, Biard C, Blount JD, Houston DC, Ninni P, Saino N, Surai PF. Carotenoid- dependent signals: Indicators of foraging efficiency, immunocompetence or detoxification ability? Avian and Poultry Biology Reviews 2000; 11(3): 137-159

Mourao JL, Pinheiro VM, Prates JAM, Bessa RJB, Ferreira LMA, Fontes CMGA, Ponte PIP. Effect of dietary dehydrated pasture and citrus pulp on the performance and meat quality of broiler chickens. Poultry Science 2008;87:733-743.

Negro JJ, Bortolotti GR, Tella JL, Fernie KJ, Bird DM. Regulation of integumentary colour and plasma carotenoids in American Kestrels consistent with sexual selection theory. Functional Ecology 1998:12:307-312.

Negro JJ, Tella JL, Blanco G, Forero MG, Garrido-Fernandez J. Diet explains interpopulation variation of plasma carotenoids and skin pigmentation in nestling white storks. Physiological and Biochemical Zoology 2000;73:97-101

Northcutt JK. Factors affecting poultry meat quality. Bulletin 2009; 1157: April, the University of Georgia and Ft. Valley State College, the U.S. Georgia: Fort Valley University of Georgia.

Novotny NA, Harrison DJ, Pawlosky R, " Vincent P, Flanagan VP, Kurilic $A C$. $\beta$-Carotene conversion to vitamin $A$ decreases as the dietary dose increases in humans. Journal of Nutrition 2010;140(5):915-918.
Ozkan S, Malayoglu HB, Yalcin S, Karadas F, Kocturk S, Cabuk M, Ozdemir S, Ozdemir E, Ergül, M. Dietary vitamin e ( $\alpha$-tocopherol acetate) and selenium supplementation from different sources: performance, ascites-related variables and antioxidant status in broilers reared at low and optimum temperatures. British Poultry Science 2007;48:580-593.

Pennisi E. Colorful males flaunt their health. Science 2003;300 (5616):2931.

Pérez-Vendrell AM, Hernández JM,Llaurado L, Schierle J, Brufau J. Influence of source and ratio of xanthophyll pigments on broiler chicken pigmentation and performance. Poultry Science 2001;80:320-326.

Peters A, Denk AG, Delhey K, Kempenaers B. Carotenoid-based bill colour as an indicator of immune competence and sperm performance in male mallards. Journal of Evolutionary Biology 2004;17(5):1111-1120.

Petracci M, Betti M, Bianchi M, Cavani C. Color variation and characterization of broiler breast meat during processing in Italy. Poultry Science 2004:83:2086-2092.

Poor CL, Miller SD, Fahey GC, Easter RA, Erdman JW. Animal models for carotenoid utilization studies: evaluation of the chick and the pig. Nutrition Reports International 1987;36:229-234

Prager M, Johansson ET, Andersson S. Differential ability of carotenoid C4-oxigenaration in yellow and red bishop species (Euplectes spp.).Comparative Biochemistry and Physiology Part B 2009;150:373380

Qureshi MA, Petitte JN, Laster SM, Dietert RR. Avian macrophages: contribution to cellular microenvironment and change in effector functions following activation. Poultry Science 1993;72:1280-1284.

Rama Rao SV, Raju MVLN, Panda AK, Poonam NS, Shyam Sunder G. Effect of dietary $\alpha$-tocopherol concentration on performance and some immune responses in broiler chickens fed on diets containing oils from different sources. British Poultry Science 2011;52:97-105.

Rebolé A, Rodríquez ML, Ortiz LT, Alzueta C, Centeno C, Viveros A Brenes A, Arija I. Effect of dietary high-oleic acid sunflower seed, plam oil and vitamin E supplementation on broiler performance, fatty acid composition and oxidation. British Poultry Science 2006;47:581-591

Royle NJ, Surai PF, Mccartney RJ, Speake BK. Parental investment and egg yolk lipid composition in gulls. Functional Ecology 1999;13:298-306.

Rubolini D, Romano M, Bonisoli Alquati A, Saino N. Early maternal, genetic and environmental components of antioxidant protection, morphology and immunity of yellow-legged gull (Larus michahellis) chicks. European Society for Evolutionary Biology 2006;19(5):1571-1584.

Ruiz JA, Perez-Vendrell AM, Esteve-Garcia E. Effect of beta-carotene and Vitamin $E$ on oxidative stability in leg meat of broilers fed different supplemental, fats. Journal of Agriculture and Food Chemistry 1999;47:448-454.

Saino N, Calza S, Møller AP. Immunocompetence of nestling barn swallows (Hirundo rustica) in relation to brood size and parental effort. Journal of Animal Ecology 1997;66:827-836.

Saino N, Ferrari R, Romano M, Martinelli R, Møller AP. Experimental manipulation of egg carotenoids affects immunity of barn swallow nestlings. Proceedings Royal Society London B 2003;270:2485-2489.

Schiedt K, Leuenberger FJ, Vecchi M, Glinz E, Absorption, retention and metabolic transformations of carotenoids in rainbow trout, salmon and chicken. Pure and Applied Chemistry 1985;57:685-692.

Schiedt K. Absorption and Metabolism of carotenoids in birds, fish and crustaceans. In: Britton G, Liaaen-Jensen S, Pfander, $H$, editors. Carotenoids. Biosynthesis and metabolism. Boston: Birkhauser; 1998. p.285-358. 
Selle PH, Celi P, Cowieson A. Effects of organic selenium supplementation on growth performance, nutrient utilisation and selenium tissue concentrations in broiler chickens. Proceedings of the 24th Australian Poultry Science Symposium (APSS). Veterinary Science Conference Centre; 2013 Fev 17-20; Sydney, AU. Sydney: University of Sydney; 2013

Sepp T, Karu U, Sild E, Männiste M, Hõrak P. Effects of carotenoids, immune activation and immune suppression on the intensity of chronic coccidiosis in greenfinches. Experimental Parasitology 2011;127:651657.

Shekaro A, Oladele SB, Abdu PA, Ibrahim NDG. Effect of selenium on the susceptibility of vaccinated cockerels against infectious bursal disease. Journal of Veterinarian Advance 2012;2(12):573-579.

Siegel PB, Larsen CT, Emmerson DA, Geraert PA, Picard M. Feeding regimen, dietary vitamin $E$, and genotype influences on immunological and production traits of broilers. Journal of Applied Poultry Research 2000;9:269-278

Sikder AC, Chowdhury SD, Rashid MH, Sarker AK, Das SC. Use of dried carrot meal (DCM) in laying hen diet for egg yolk pigmentation. AsianAustralasian Journal of Animal Science 1998:11:239-244.

Skrivan M, Dlouha G, Masata O, Sevcekova S. Effect of dietary selenium on lipid oxidation, selenium and vitamin e content in the meat of broiler chickens. Czech Journal of Animal Science 2008;53:306-311.

Sunder A, Flachowsky G. Influence of high vitamin E dosages on retinol and carotenoid concentration in body tissues and eggs of laying hens. Archices für Tierernährung 2001;55:43-52.

Surai PF, Sparks NHC. Comparative evaluation effect of two maternal diets on fatty acids, vitamin $\mathrm{E}$ and carotenoids in the chicken embryo. British Poultry Science 2001;42:252-259.

Surai PF, Speake BK, Sparks NHC. Carotenoids in avian nutrition and embryonic development. 1. Absorption, availability and levels in plasma and egg yolk. Journal of Poultry Science 2001a;38(1):1-27.

Surai PF, Speake BK, Wood NAR, Blount JD, Bortolotti GR, Sparks NHC. Carotenoid discrimination by the avian embryo: A lesson from wild birds. Comparative Biochemistry Physiology 2001b;4:743-750.

Surai PF. Natural antioxidants in avian nutrition and reproduction. Nottingham: Nottingham University Press; 2002.

Surai PF. Selenium in nutrition and health. Nottingham: Nottingham University Press; 2006.

Surai PF. The antioxidant properties of canthaxanthin and its potential effects in the poultry eggs and on embryonic development of the chick. Part 1. World's Poultry Science Journal 2012;68:465-476.
Tachibana K, Yagi M, Hara K, Mishima T, Tsuchimoto M. Effects of feeding of $\beta$-carotene-supplemented rotifers on survival and lymphocyte proliferation reaction of fish larvae (Japanese parrotfish (Oplegnathus fasciatus ) and spotted parrotfish (Oplegnathus punctatus)): preliminary trials. Hydrobiologia 1997;358:313-316.

Tanumihardjo SA. Assessing vitamin A status: past, present and future. Journal of Nutrition 2004;134:290S-293S.

Tayeb IT, Qader GK. Effect of fed supplementation of selenium and vitamin $\mathrm{E}$ on production performance and some hematological parameters of broiler. Kahraman Maraş Sütcü Imam University Journal of Natural Sciences 2012;15:46-56.

Tella JL, Negro JJ, Rodriquez-Estrella R, Blanco G, Forero MG, Blazquez MC, Hiraldo F. A comparison of spectrophotometry and color charts for evaluating total plasma carotenoids in wild birds. Physiological Zoology 1998:71:708-711

Tengerdy RP, Lacetera NG, Nockels CF. Effect of carotenoids ease protection and humoral immunity in chickens. Avian Disease 1990;34:848-854

Tengerdy RP, Nockels CF. Vitamin E or vitamin A protects chickens against $E$. coli infection. Poultry Science 1975;54:1294-1296.

Tyczkowski JK, Hamilton PB. Absorption, transport, and deposition in chickens of lutein diester, a carotenoid extracted from marigold (Tagetes erecta) petals. Poultry Science 1986;65:1526-1531.

Van Eck JHH, Goren E. An Ulster 2C strain-derived Newcastle 283 disease vaccine: vaccinal reaction in comparison with other lentogenic Newcastle 284 disease vaccines. Avian Pathology 1991;20:497-507.

Van Laack RLJM, Liu CH, Smith MO, Loveday HD. Characteristics of pale, soft, exudative broiler breast meat. Poultry Science 2000;79:10571061

Waldenstedt L, Inborr J, Hansson I, Elwinger K. Effects of astaxanthinrich algal meal (Haematococcus pluvalis) on growth performance, caecal campylobacter and clostridial counts and tissue astaxanthin concentration of broiler chickens. Animal Feed Science and Technology 2003;108:119-132

Woodall AA, Britton G, Jackson MJ. Dietary supplementation with carotenoids: effects on alpha-tocopherol levels and susceptibility of tissues to oxidative stress. British Journal of Nutrition 1996:76:307-317.

Yeum KJ, Russell RM. Carotenoids bioavailability and bio conversion. The Annual Review of Nutrition 2002;22:483-504.

Zelenka F, Fajmonova E. Effect of Age on utilization of selenium by chickens. Poultry Science 2005;84:543-546. 
